Finance and Economics Discussion Series Divisions of Research \& Statistics and Monetary Affairs Federal Reserve Board, Washington, D.C.

\title{
How Did the 2003 Dividend Tax Cut Affect Stock Prices and Corporate Payout Policy?
}

\section{Gene Amromin, Paul Harrison, Nellie Liang, and Steve Sharpe} 2005-57

NOTE: Staff working papers in the Finance and Economics Discussion Series (FEDS) are preliminary materials circulated to stimulate discussion and critical comment. The analysis and conclusions set forth are those of the authors and do not indicate concurrence by other members of the research staff or the Board of Governors. References in publications to the Finance and Economics Discussion Series (other than acknowledgement) should be cleared with the author(s) to protect the tentative character of these papers. 


\title{
How Did the 2003 Dividend Tax Cut Affect Stock Prices and Corporate Payout Policy?*
}

\author{
Gene Amromin, Paul Harrison, Nellie Liang, Steve Sharpe
}

Draft: September 26, 2005

\begin{abstract}
*This work is a synthesis prepared for the October $7^{\text {th }}$ Federal Reserve Board Academic Consultants meeting based, in part, on two papers: "How Did the 2003 Dividend Tax Cut Affect Stock Prices?” by Gene Amromin, Paul Harrison, and Steve Sharpe, and "Executive Financial Incentives and Payout Policy: Firm Responses to the 2003 Dividend Tax Cut,” by Jeffrey Brown, Nellie Liang, and Scott Weisbenner. The views expressed are those of the authors and not necessarily those of the Federal Reserve Board or the Federal Reserve Bank of Chicago.
\end{abstract}




\section{Introduction}

The Jobs and Growth Tax Relief Reconciliation Act of 2003 was signed into law by the President on May $28^{\text {th }}$. Among several provisions, the reduction in the maximum statutory tax rate on dividends from 38 percent to 15 percent was perhaps the most dramatic and was almost certainly the most contentious. Indeed, the Senate passed the bill with a vote of 51-50, following weeks of wrangling, during which time it was unclear whether the Senate could pass a version of the bill that would contain anything close to the eventual reduction in dividend taxes. A related provision in the ultimate package was a reduction to the top statutory rate on long-term capital gains taxes from 20 percent to 15 percent, thereby equalizing those two tax rates for the first time since 1990.

The purported benefits of these provisions were manifold. It was argued that the reduction in the dividend tax rate would encourage more companies to pay dividends, which would facilitate both the redistribution of capital resources and corporate governance reform. Another purported benefit was that the reduction in taxes on investment income would lower the cost of capital to business, thereby stimulating more investment and job creation. This lower cost of capital would be effected through a rise in U.S. corporate equity prices, which, in turn, was expected to boost spending through the wealth effect.

In this paper, we test the hypothesis that the proposed cut in capital taxation boosted U.S. equity prices. We use an event-study methodology to compare the behavior of U.S. common stock prices to the prices of securities on which capital taxation should have seen little or no direct effect, such as stock prices of foreign firms, as well as the prices of equity securities on real estate investment trusts (REITs). In addition, we analyze the impact of the news by examining cross-sectional differences in the response of stock prices, comparing in particular firms with different dividend policies.

In the final section, this paper examines the response of corporate dividend policy, which other studies have shown to be dramatic. The analysis here goes a couple steps further, in order to determine what factors might have influenced the varied level of responses to the new tax law, and to measure whether the positive dividend effect also represented a net boost to total corporate payouts or, instead, a substitution away from stock repurchases. 
Summarizing our conclusion, we fail to find much, if any, imprint of the dividend tax cut news on the value of the aggregate stock market. Second, there appeared to have been modest but seemingly short-lived cross-sectional effects on stock valuations. Finally, changes to payout policy following passage of the tax bill were systematically related to executive compensation structure but resulted in only a muted gain in total corporate payouts.

\section{Announcement and Passage of a Dividend Tax Cut: A Narrative}

For our formal analysis we define two narrow event windows when news on political developments presumably raised the likelihood that a substantial dividend tax cut would be enacted - the shaded areas in Figure 1. The first event period surrounds Bush's January 7 speech to the Economics Club of Chicago, when the dividend tax cut proposal was officially unveiled (see the list of key event dates in Figure 1). Because the intention to propose a dividend tax cut was leaked in a January 3rd Washington Post article, the window spans January 3-9, capturing the period over which newspaper coverage initially spiked. One measure of media coverage is shown by the vertical bars in Figure 1, which plot the daily number of news stories containing the topic of "dividends" and "taxes" in the 15 largest U.S. newspapers. The number of such stories quickly subsided during February through April as legislation made scant progress and the public focused on the prospect of war in Iraq.

The issue became a prime news story again in early May, following reports that House Republican leaders had finally agreed on a specific tax package containing a provision to lower the top tax rate on corporate dividends to 15 percent. Nonetheless, prior to mid-May it remained unclear whether any substantial cut in dividend taxes could

pass the Senate. For instance, a May $5^{\text {th }}$ article in the Wall Street Journal led off with: “The Senate Finance Committee's tax package probably won't include any of the dividend-tax relief that President Bush wants, although it will leave room for a smaller version of the benefit if Republicans can muster support for it.” On May 9 the Journal reported that the Senate Finance Committee agreed to include as part of the Senate tax package a much scaled-back benefit. That tax package - which included only miniscule 
dividend tax relief compared to the original proposal - was expected to see "rougher waters” on the Senate floor.

However, a breakthrough was reported on May 15 in the New York Times, specifically, that the previous day "a bipartisan group of senators reached agreement with Republican leaders... adding a crucial Democratic vote to President Bush’s plan for eliminating taxes on dividends.” Indeed, on May 15, three Democrats joined 48 Republicans to pass a package under which “investors can exclude 50 percent of dividend income from taxes this year and 100 percent of such income in” 2004-2006, after which point the tax would be reinstated in full.

Consequently, we propose a second event period which begins with May $14^{\text {th }}$, the day of the first major breakthrough in Senate negotiations. The last obstacle was breached with Senate passage of the compromise legislation early in the morning on May $23^{\text {rd }}$, but we let the formal event window runs through May 28, two business days later, when the president signed the bill. ${ }^{1}$

As shown in the chart, stock market gains during the two tax-cut event windows are relatively modest and appear to be swamped by the slump and rebound of share prices around the threat and then realization of war in Iraq. In particular, as reported by the Wall Street Journal on March $17^{\text {th }}$, news that the U.S, Britain and Spain announced an end to their efforts to win UN support for a war, and of an impending televised address by Bush, sent the S\&P 500 soaring 3-1/2 percent that day alone. Investors were apparently relieved by the resolution of the uncertainty about if and when the war would commence.

Over the January 3-9 window, the S\&P 500 and the Russell 2000 small-cap index rose about 2 percent and 1 percent, respectively. Over the May 14-28 window, the S\&P 500 rose 1.2 percent, while the small-cap index rose 2.7 percent. (Including May 6-13 would boost the second-window returns to 2.9 and 5 percent, respectively.) Of course, the aggregate market could have been buffeted by other, very unfavorable news during those windows; thus, the analysis to follow examines excess returns across markets or in

\footnotetext{
${ }^{1}$ Alternatively, we could have started the second event period on May 6, the day the House Ways and Means Committee approved a \$550 billion tax package with a provision for lower dividend tax rates. As will be seen, starting the event period instead on May 6 does not alter the qualitative conclusions, but reduces the power of our tests by widening the confidence bands.
} 
the cross-section of U.S. stocks in order to gauge the effect of the dividend tax cut on equity valuations.

\section{Broad Market Evidence}

Although our empirical analysis of the effects of the 2003 dividend tax cut on the stock market takes on several guises, the methodology is similar in all cases. In this section, we present three tests contrasting the change in value of a portfolio of U.S. common stocks that currently (or prospectively) generate taxable dividend streams with the change in value of a control portfolio of securities during the two event windows. In each case, the tax cut legislation under consideration can be reasonably presumed to have little or no direct effect on the valuation of the control portfolio. Thus, by examining the relative returns on U.S. common stocks, we can in principle control for the effects of general economic news.

Our first two tests compare U.S. stock market returns with returns on foreign equities. The prospect of the dividend tax cut would be applicable only to investors subject to the U.S. tax law, and U.S. investors hold a relatively small fraction of foreign equities - between 10 to 15 percent in most European markets. ${ }^{2}$ In addition, the benefit of the tax cut to a U.S. owner of foreign stocks is typically far less than the benefit received on U.S. company dividends because the U.S. taxpayer's overall tax liability on a foreign stock equals the maximum of the U.S. and foreign country dividend tax rates.

Figures 2 and 3 present formal tests for excess positive returns on the U.S. stock market relative to foreign counterparts. The top panels of Figure 2 show the levels of two broad large-cap stock market indexes - the S\&P 500 and S\&P Euro 350 (IShares) surrounding the key time periods. The latter index tracks large firms domiciled in continental Europe, covering about 70 percent of the region's market capitalization and spanning 17 exchanges. ${ }^{3}$ Over both event windows, shown by the shaded areas, the performance of European stocks appears similar to, or better than, that of U.S. stocks.

\footnotetext{
${ }^{2}$ Department of the Treasury and the Federal Reserve Bank of New York, "Report on U.S. Portfolio Holdings of Foreign Securities as of December 31, 2003,” March 2005.

${ }^{3}$ An important characteristic of the S\&P 350 Euro index is that it is available to the U.S. investors in the form of an exchange-traded fund, which eliminates non-synchronicity problems associated with foreign securities traded abroad. Since the value of the exchange-traded fund is held close to the Index by arbitrage, it does not matter that the exchange-traded fund is largely owned by US investors.
} 
Although the visual evidence in the top panel is compelling, this comparison does not control for the "normal" relationship between U.S. and foreign equities. To do so, we assume that the U.S. and foreign stock indexes are influenced by a common (global) market factor, but with different loadings, or sensitivities. We then regress daily S\&P 500 returns on daily S\&P Euro 350 returns in the six months before and after the event period (July-Dec. 2002 and July-Dec. 2003), to obtain an estimate of the relative beta for the S\&P 500 during normal times. ${ }^{4}$

We find a strong positive link between returns in the two markets ( $\beta=0.66)$, with fluctuations in foreign equity returns accounting for nearly two-thirds of variation in the S\&P 500 returns. Abnormal returns are calculated as the difference between actual and model-predicted S\&P 500 returns. These abnormal returns are then cumulated over the relevant time horizon and plotted in the lower panel of Figure 2, normalized to zero at the beginning of each event window (January 2 and May 13, 2003).

If the U.S. stock market responded to the possibility of a dividend tax cut, then cumulative abnormal returns would be positive during the event periods. As shown by the thick black line in the lower left hand panel, the cumulative abnormal return from January 3-9 is estimated to be positive but small, about 2 percent. On the other hand, abnormal S\&P 500 returns over the May event window are negative, on net. Thus, during the key period where the actual form of the tax cut took shape and was adopted, the S\&P 500 did not outperform a comparably broad index of European equities.

Furthermore, daily returns were quite volatile in 2002 and 2003 and had a standard deviation of 1.5 percentage points over our estimation period. Even though much of this variance is explained by movements in the S\&P Euro 350 index, the remaining variation is large enough to generate wide standard error bounds, which increase as the event horizon lengthens. The error bounds, shown by the dotted lines, serve as an illustration of the magnitude of the stock market response necessary to overcome statistical doubts about the tax effect, a task that this exercise clearly fails.

As a robustness check, we re-estimate our results using weekly returns data, which smoothes out some day-to-day fluctuations in the market. Although the variance

\footnotetext{
${ }^{4}$ We exclude January-June 2003, the period over which the proposal is announced and debated, because the correlation between returns the two markets' returns was presumably distorted by events. Estimated abnormal returns are similar when model estimation period is 2002, but error bands are somewhat wider.
} 
of excess weekly returns is lower, their cumulative level (the thin solid line in the bottom panels) is about the same and still below zero over the May period, again indicating no measurable positive effect of the tax cut.

Small-capitalization stocks, as reflected by the Russell 2000 index, outperformed large-cap stocks over 2003, particularly around May. This observation was commonly cited in the press as a contradiction to the common wisdom regarding the expected effect of the tax cut; if anything, large-cap stocks that generally pay the higher dividends would seem to stand the most to gain. ${ }^{5}$ Some economists, however, have argued that under certain conditions it is possible for stock prices of immature firms to have benefited the most from the tax cut. ${ }^{6}$

Again, if small-cap U.S. stocks were positively affected by the tax cut, then one would expect small-cap stocks in the U.S. to have performed unusually well in comparison to foreign small-cap stocks. We examine this hypothesis in Figure 3, where the FTSE Small Cap index is used as a foreign-market counterpart to Russell $2000 .^{7}$ The lower panels of the exhibit show the resulting abnormal small cap returns estimated at both the daily (thick solid line) and weekly (thin solid line) frequencies. The abnormal returns are zero over the January event window, and are even marginally negative over the May window, again contradicting the hypothesis that the tax cut was behind the strong U.S. stock market performance.

As an alternative to using foreign markets as a control, we next consider a class of U.S. assets whose dividends were specifically excluded from the 2003 tax cut. Real estate investment trusts (REITs) do not pay taxes on their profits at the corporate level if they distribute at least $90 \%$ of their taxable profits to their investors. Although such distributions are commonly referred to as "dividends," their tax-free pass-through to investors made them ineligible for the lower dividend tax rate. Consequently, if the

\footnotetext{
${ }^{5}$ If there is uncertainty about the permanence of the dividend tax cut, firms with lower dividend yields should, presumably, experience a smaller price response. The dividend yield of the Russell 2000 is substantially lower than that of the S\&P 500 firms.

${ }^{6}$ Alan J. Auerbach and Kevin A. Hassett, "The 2003 Dividend Tax Cuts and the Value of the Firm: An Event Study,” NBER Working Paper 11449, (2005) argue that firms not paying dividends currently, but expected to issue more equity, may nevertheless experience a greater relative increase in their value.

${ }^{7}$ The FTSE Small Cap index tracks stocks trading on the London stock exchange, which creates a nonsynchronicity problem. To address this issue, in estimating a model for abnormal returns, we regress Russell 2000 returns for calendar day $t$ on FTSE Small Cap returns for calendar days $t$ and $t+1$; we also estimate a weekly version.
} 
dividend tax cut boosted the valuation of (eligible) common stocks, one would expect REIT returns to have underperformed those equity shares over the event windows; that is, abnormal REIT returns should have been negative.

As shown in the top panels of Figure 4, REIT prices (dotted green line) generally tracked the overall market for most of the event windows, even after the reconciled version of the tax legislation passed the Senate-House conference and the tax treatment of REIT distributions was made clear. Only on the day before the bill was signed into law did REIT shares decline sharply, and then only temporarily. The lower panels of Figure 4 examine the cumulative abnormal REIT returns (relative to S\&P 500 returns).

Abnormal returns are near zero during the event windows and well within the estimated error bounds and are modestly positive by the end of July. Having found little measurable effect of the dividend tax cut on aggregate U.S. stock valuations, in the next section we attempt to determine whether the legislation had any significant crosssectional effects on U.S. stock valuations.

\section{Cross-sectional Evidence}

In the simplest of worlds without uncertainty, and where corporate net income is eventually paid out as dividends, a once-and-for-all cut in the dividend tax rate would have a similar positive valuation effect on all common stocks, regardless of their current dividend yield. Perhaps the most obvious complication is the recognition of uncertainty about the permanence of any tax reform, given the frequency of such changes over the past 75 years. Moreover, the 2003 law and its early incarnations explicitly embedded sunset provisions. Indeed, the reduced dividend tax rate will expire in 2008, absent additional legislative action. Together with growing budget deficits and changeable political priorities, the sunset provision undoubtedly added to the usual degree of uncertainty about the duration of the benefit. ${ }^{8}$

Uncertainty regarding the permanence of a dividend tax cut should dampen the positive valuation effect on all stocks, but more so on stocks for which the lion's share of

\footnotetext{
${ }^{8}$ Low-dividend firms tend to be concentrated in growth industries, where firm survival and thus eventual payment of dividends is more uncertain. Consequently, low-payout firms may be construed to have riskier dividend streams inducing risk-averse investors to discount some of the tax benefit and generating a second-order effect on the relationship between payout rates and response to a tax cut.
} 
dividends will be paid far into the future - stocks that currently pay little or no dividend. Accordingly, we look for cross-sectional effects of the proposed dividend tax cut by splitting our sample of more than 2800 firms into four groups based on their dividend yield in 2002, shown in Table 1. As noted, just over half of the firms did not pay any dividend in 2002. We define high-dividend firms as those for which the ratio of 2002 dividends to end-of-year price ("dividend yield") is greater than 3 percent, about a fifth of the dividend-payers. Medium-dividend firms have a dividend yield between 1 and 3 percent, while low-dividend firms are those with a dividend yield of less than 1 percent. Summary statistics for each group are presented in Table 1. The zero-dividend firms are notably smaller, more investment intensive, and less debt reliant than the other groups.

The top panels of Figure 5 show the cumulative realized returns for each group (equal-weighted) over the two event periods. The cumulative return ranged between 1 and 2 percent during the January 2003 event window for each group. During the May event period, the high-dividend and zero-dividend portfolios logged gains of approximately five percent, somewhat more than the other portfolios. ${ }^{9}$ Because risk characteristics probably vary systematically across these groups, we test for differential performance by computing abnormal returns using the Fama-French three-factor model estimated over a twelve month period that includes the six months prior and subsequent to the event period. Conclusions are insensitive to choice of the factor estimation period.

As seen in the bottom panels of Figure 5, the high-dividend portfolio generated abnormal returns of around 1 percent in the January window and 2-3/4 percent in the May window. Interestingly, in the latter period, it appears that high-dividend stocks began to diverge from low- and medium-dividend stocks on May $14^{\text {th }}$, a pattern that persisted until the day before the legislation was signed. As Table 2 shows formally, in columns 3 and 4, the abnormal returns of the high-dividend firms over both event windows are statistically different from zero and from the abnormal returns of the lowdividend firms. Even so, Figure 5 also shows that this performance differential is not persistent, and by July it has dissipated entirely. ${ }^{10}$

\footnotetext{
${ }^{9}$ Results are qualitatively similar for value weighting.

${ }^{10}$ One interpretation is an appeal to temporary illiquidity; a quick response by alert tax-sensitive investors might have been eventually arbitraged away by nontaxable investors making offsetting portfolio changes.
} 
On the other hand, the bottom panel of Figure 5 also shows that firms at the other end of the payout spectrum - zero-dividend firms - logged positive abnormal returns of 1-1/2 percent in the May window, which are marginally statistically significant. These results seem to present a puzzle. The positive abnormal returns on stocks with higher current dividend yield is consistent with theoretical predictions of the effect of a temporary tax cut for firms currently paying dividends. Yet, the out-performance of zero-dividend stocks relative to low-dividend stocks over the tax-cut event window seems to cast some doubt on that interpretation.

One possibility is that the abnormal returns on zero-dividend stocks are spurious. In particular, it appears from the chart that, unlike high-dividend firms, the abnormal performance of zero-dividend firms does not appear to be tied to the event period, but rather runs almost continuously from mid-April through July. This suggests that something else may be driving this result; for instance, the risk-factor model used to estimate normal returns for these firms could be substantially mis-specified. ${ }^{11}$

Nonetheless, we consider this seemingly anomalous result in more detail. One explanation for a positive, and potentially larger, response of zero-dividend share prices to a dividend tax cut is proposed by Auerbach and Hassett (2005). They presume that zero-dividend firms will need to issue equity in the future because such firms will be unable to satisfy their large investment needs with internal funds or by issuing interestbearing debt. Current shareholders then reap the windfall on dividends to be paid on shares yet to be issued, causing an inflated response of the prospective issuer's current market value to a cut in dividend taxes. ${ }^{12}$

One approach to testing this explanation is to identify those zero-dividend firms that are likely to be truly equity-issuance dependent and compare their abnormal returns to other zero-dividend firms for which this story seems less plausible. We show one such experiment in Figure 6. Here, we compare the abnormal returns of (zero-dividend paying) firms that used some of their cash to repurchase shares in recent years to the

\footnotetext{
${ }^{11}$ In order to test whether the performance differential between high- and low-dividend stocks is spurious, we examined the abnormal bond returns for the two groups of firms and found no evidence of abnormal bond returns for either group, suggesting that the equity performance gap is driven by the tax event which favors firms' equity but not debt. We considered a similar test for the zero-dividend group, but only a small non-representative fraction of those firms have bonds outstanding.

${ }^{12}$ Of course, the benefits of a temporary tax cut are still smaller than from a permanent cut since the tax break may expire before a firm decides to pay dividends.
} 
abnormal returns of those firms that did not repurchase shares. The basic hypothesis is that firms that have been repurchasing shares are less likely to be cash-flow constrained and thus less likely to be anticipating a need to issue equity in the future.

As can be seen, there is virtually no difference between the abnormal performance of zero-dividend firms that have repurchased shares and those that have not done so. Furthermore, as detailed in the Appendix, an examination of equity issuance by zero dividend firms since the tax cut indicates that the split by repurchase activity is a valid instrument, or predictor, of future equity issuance: zero-dividend firms that have recently bought back their stock were less likely to issue equity in the future compared to (zerodividend) firms that did not repurchased shares. This result casts further doubt on the above-mentioned rationale for the apparent positive abnormal event-window returns by zero-dividend firms. ${ }^{13}$

\section{Pay-out Policy Evidence}

Several studies have documented that, over the four quarters following the passage of the tax cut, there was a marked rise in the number of special dividends, initiations of new regular dividends, and large increases in regular dividends. This is illustrated in Figure 7, where the number of dividend initiations by publicly-traded firms, and the four-quarter growth in the amount of dividends paid per share by S\&P 500 firms, spike in the quarter immediately following the tax cut, and remain persistently high for several quarters thereafter.

To explain the cross-sectional response of dividend increases to the tax cut and to assess the effect of the tax-law change, we relate dividend increases to a number of explanatory variables and contrast results for 2003 with those for the previous decade. ${ }^{14}$

Of special interest is the role of executive stock and option holdings, which tie executives' personal wealth to the value of the firm. Like other shareholders, executives with large holdings of stock benefit substantially from the dividend tax cut, with the

\footnotetext{
${ }^{13}$ We conducted a number of alternative splits among the zero-dividend firms and found a couple cases where a presumed proxy for cash flow constraints (such as growth in capital stock) did result in sample splits with a differential in abnormal returns consistent with the proposed rationale; however, those proxies did not appear to be useful instruments for predicting actual post-tax-cut equity issuance.

${ }^{14}$ These results are from Jeffrey R. Brown, Nellie Liang, and Scott Weisbenner, "Executive Financial Incentives and Payout Policy: Firm Responses to the 2003 Dividend Tax Cut,” NBER Working Paper 11002, December 2004.
} 
after-tax value of $\$ 1$ in dividends rising from 65 cents to 85 cents. ${ }^{15}$ In contrast, executives that are compensated primarily with executive stock options almost never receive dividends paid on shares; thus, they see only the downside effect of a boost in dividends on the value of their options. Consequently, executives with options have an extra incentive to limit dividends, which was unaffected by the change in tax laws.

Our analysis is based on firms in the S\&P 1500, a large proportion of publicly traded companies, excluding very small-cap firms. Overall, 31 percent of the firms in our sample initiated or increased dividends in 2003 (Table 3, top panel). Breaking that statistic down, 7 percent of firms that did not pay dividends in 2002 initiated dividends in 2003, up from a 1-1/2 percent initiation rate in 2002. On the other hand, 57 percent of dividend-payers increased dividends, compared to 49 percent in 2002.

The data on stock and option holdings suggests that top executives hold substantial wealth in their companies and that the proportion of wealth held in options versus dividend-eligible stock varies quite a bit across firms. Consider the ratio of the number of shares held to the number of shares plus options: this figure ranges from 11.4 percent to 53.6 percent between the $25^{\text {th }}$ to $75^{\text {th }}$ percentiles of the distribution. We relate dividend increases at S\&P 1500 firms to executive shares of stock and options, holding constant various firm characteristics, such as free cash flow, cash assets on hand, growth opportunities, leverage, past performance, volatility, age, and 3-digit SIC industry.

Coefficient estimates on stock and option holdings for top executives suggest that the effect of the tax cut on dividend policy was strongest at firms where the executive's personal financial gains were most positively affected by the tax cut (Table 4). As shown in column 1, the coefficient on executive share holdings is positive and significant, whereas the coefficient on options held is negative and significant. A sense of the magnitude of these effects is most easily inferred from the second specification, where the key independent variable is the ratio of shares held to the total number of shares and options held. The coefficient of 19.6 indicates, for instance that raising that ratio by 0.5 (well within the relevant range) would increase the probability of a dividend increase by 9.8 percent $(19.6 * 0.5)$.

\footnotetext{
${ }^{15}$ Executives with large (non-diversified) stock holdings may place additional value on dividends for liquidity reasons, stemming from restrictions on their ability to sell stock and the desire to avoid the negative signal of insider sales.
} 
In columns 3 and 4, we look at dividend initiations alone, which are generally seen as more dramatic announcements than a simple dividend increase. The coefficient on the ratio of shares to shares plus options in the column 4 regression is 12.9. That would imply that shifting the compensation ratio by 0.5 would increase the likelihood of a dividend initiation by $6 \frac{1}{2}$ percentage points, which is quite substantial relative to an average 2003 initiation probability of 7 percent.

A second question we consider is the effect of the tax law change on total payouts. Higher dividends will result in higher payouts only if firms do not simply shift to dividends what would have been paid out as share repurchases. ${ }^{16}$ In table 5, we examine both dividends and share repurchases for those firms that increased dividends. As shown in the top row of the upper panel, we find that among firms initiating dividends in 2003, 68 percent had repurchased shares in 2002 and 78 percent of those firms reduced their share repurchases from their 2002 level. On net, only two-thirds of the firms that initiated dividends in 2003 also increased total payouts. ${ }^{17}$ This result provides a striking contrast with the previous decade (1993 to 2002), when 89 percent of firms that initiated dividends in any given year also increased total payouts in that year.

Finally, among dividend-paying firms that increased their dividends in 2003, only 49 percent increased their total payout in 2003, somewhat less than in previous years. As above, these results indicate that, for many firms, the increase in dividends came at the expense of repurchases. In additional analysis (not shown here), we examine the effect of executive compensation on total payout, and find that, despite their proclivity to increase dividends, firms with greater executive stock holdings were not more apt to increase total payouts.

Overall, the analysis of payout behavior indicates that the dividend tax cut did prompt a substitution from repurchases to dividends, but the effect on total payouts was

\footnotetext{
${ }^{16}$ The tax bill not only cut the top marginal rate on dividends from 35 to 15 percent, but it also cut the capital gains rate that applies to share repurchases from 20 to 15 percent. As a result, repurchases are still tax-advantaged because the tax is deferred until the capital gains are realized, although the advantage is considerably smaller. If firms had been paying out with share repurchases and switched to dividends, the tax burden actually might not fall.

${ }^{17}$ We also compared share repurchases and payouts during the year a firm increased dividends to the firm's average level of dividends and repurchases over the past three years (as opposed to just the prior year). The results regarding dividend substitution are very similar. For example, only $58 \%$ of dividend-initiators in 2003 increased total payouts above their average payout-to-assets ratio over the past three years (79\% of dividend-initiators over the period 1993-2002 increased payouts relative to the prior three-year average).
} 
much more muted. Apparently, firms for which the higher tax burden on dividends was an impinging factor had used share repurchases as tax-advantaged alternative. With an equalization of statutory rates, such firms became more willing to substitute towards dividends and scale back repurchases, leaving total payouts little changed. 
Figure 1

\section{Stock Prices and News on Dividend Tax Cut}

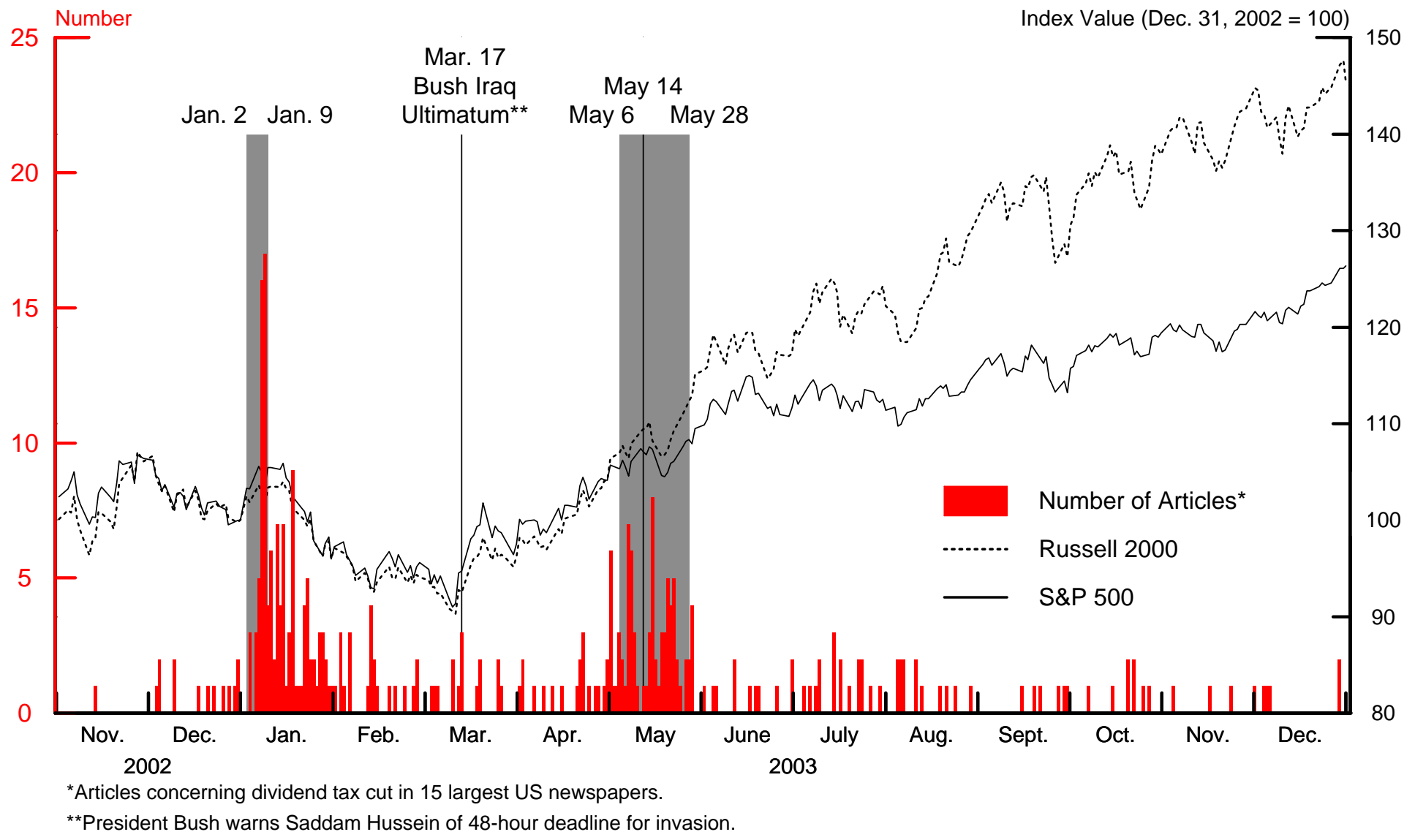

Key Event Dates for Dividend Tax Cut

$\begin{array}{ll}\frac{\text { Date }}{1 / 7 / 2003} & \text { Description } \\ 5 / 6 / 2003 & \text { Wush announces proposal } \\ 5 / 9 / 2003 & \text { House passes version } \\ 5 / 15 / 2003 & \text { Senate passes version } \\ 5 / 23 / 2003 & \text { Reconciled version passes conference } \\ 5 / 28 / 2003 & \text { President signs }\end{array}$


Figure 2

\section{S\&P 500 versus S\&P Euro $\mathbf{3 5 0}$ (Ishares)}

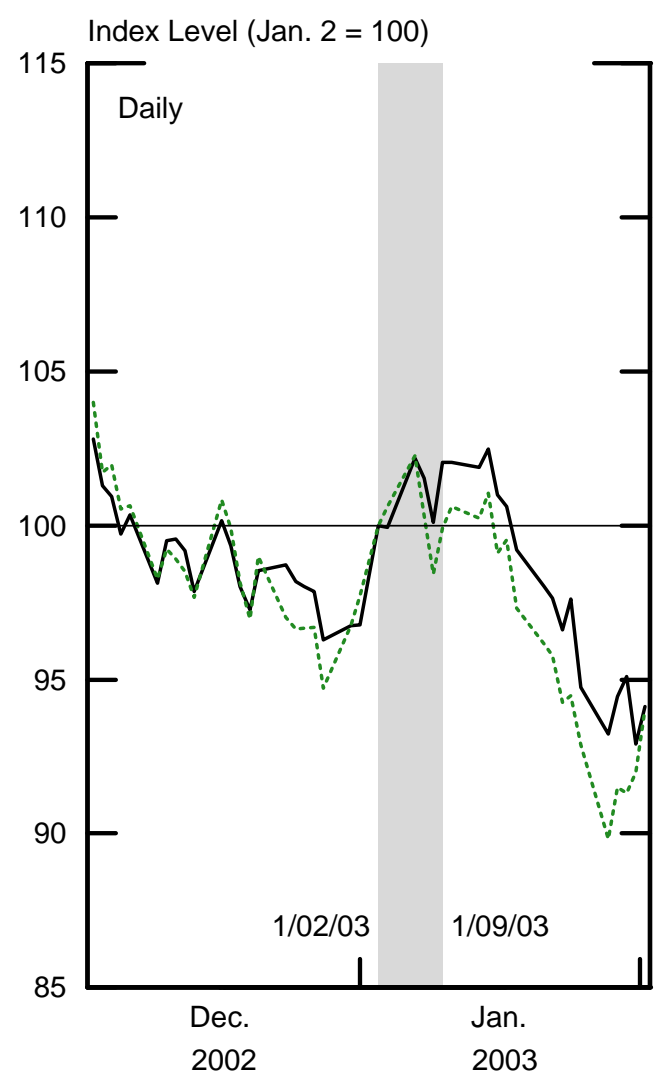

Realized Returns
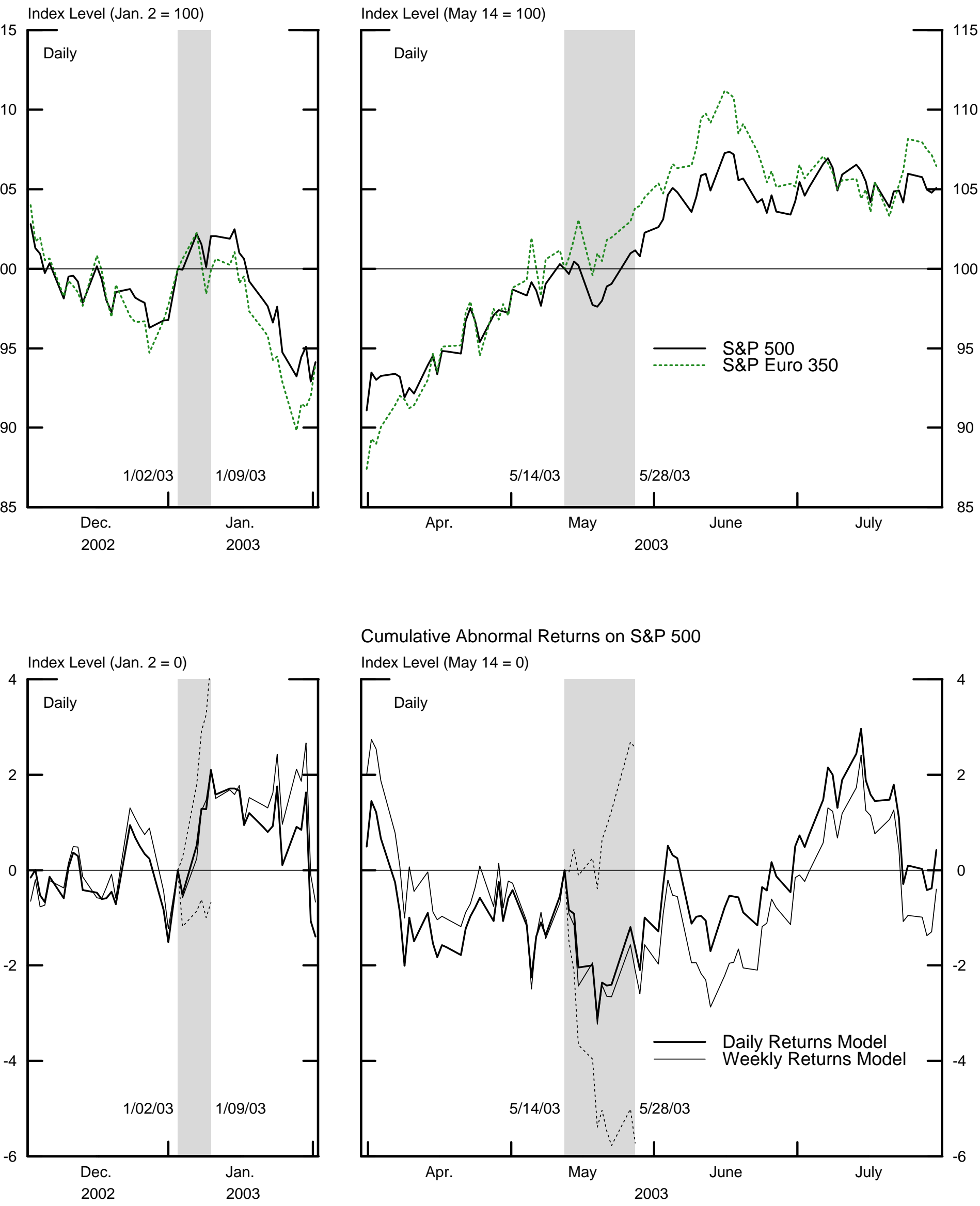

Cumulative Abnormal Returns on S\&P 500

Index Level (May 14 =0)

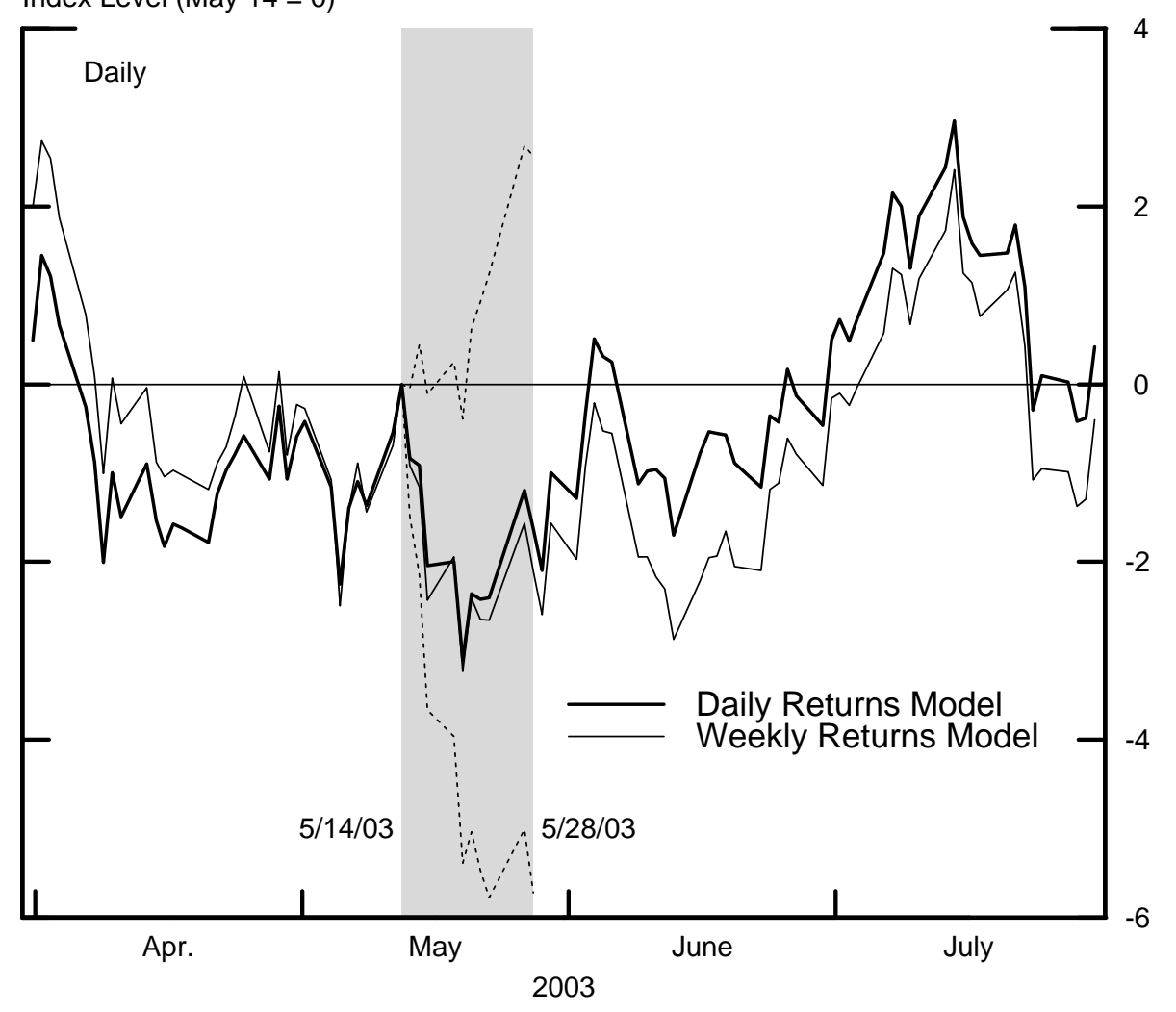


Figure 3

\section{Russell 2000 versus FTSE Small Cap}

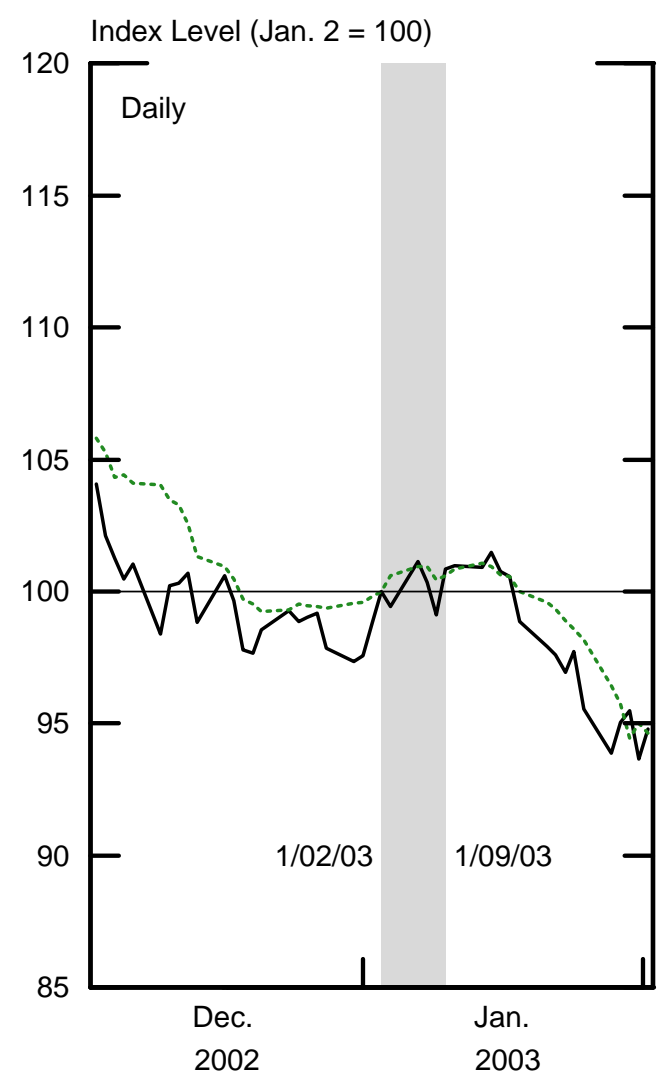

Realized Returns
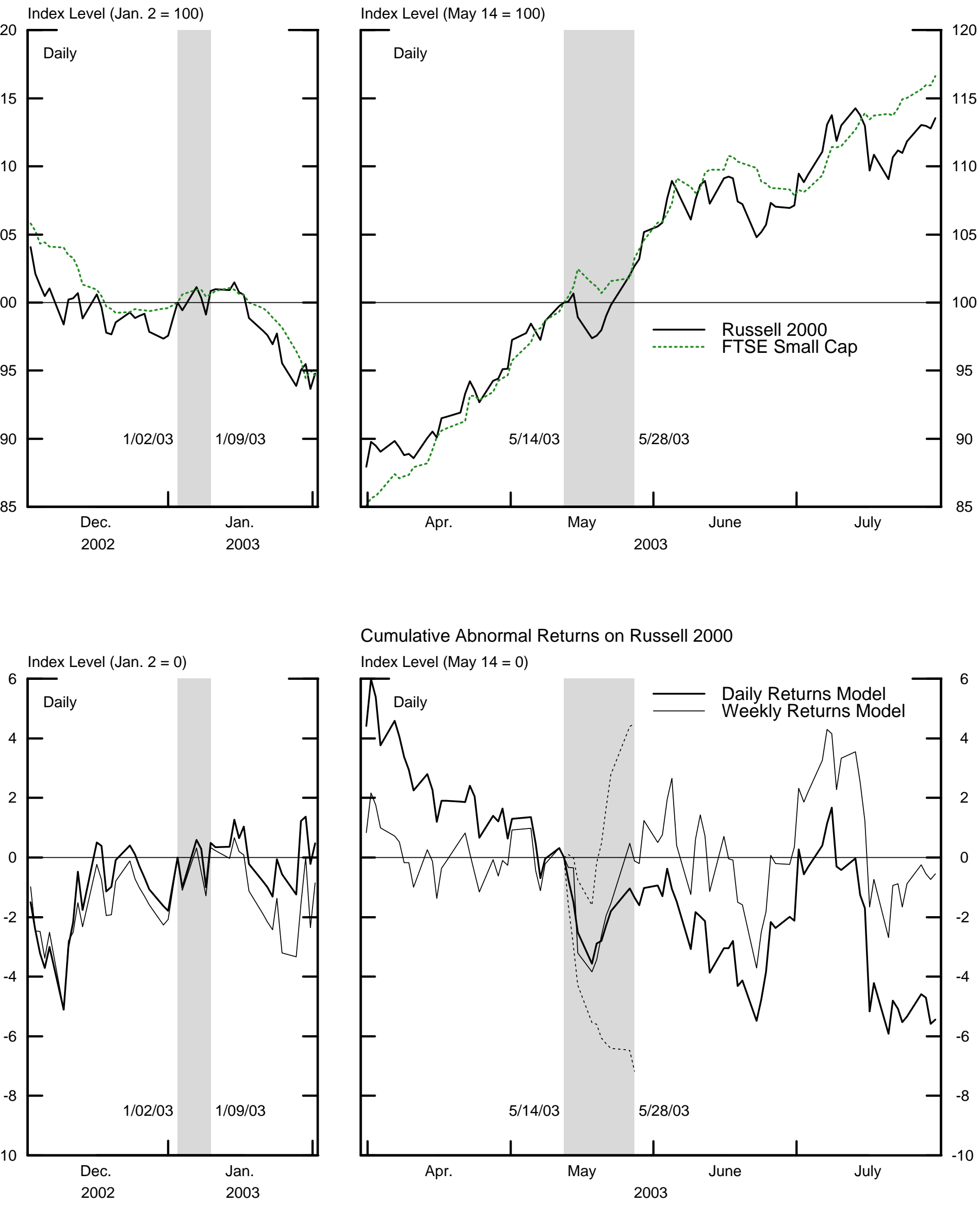

Cumulative Abnormal Returns on Russell 2000

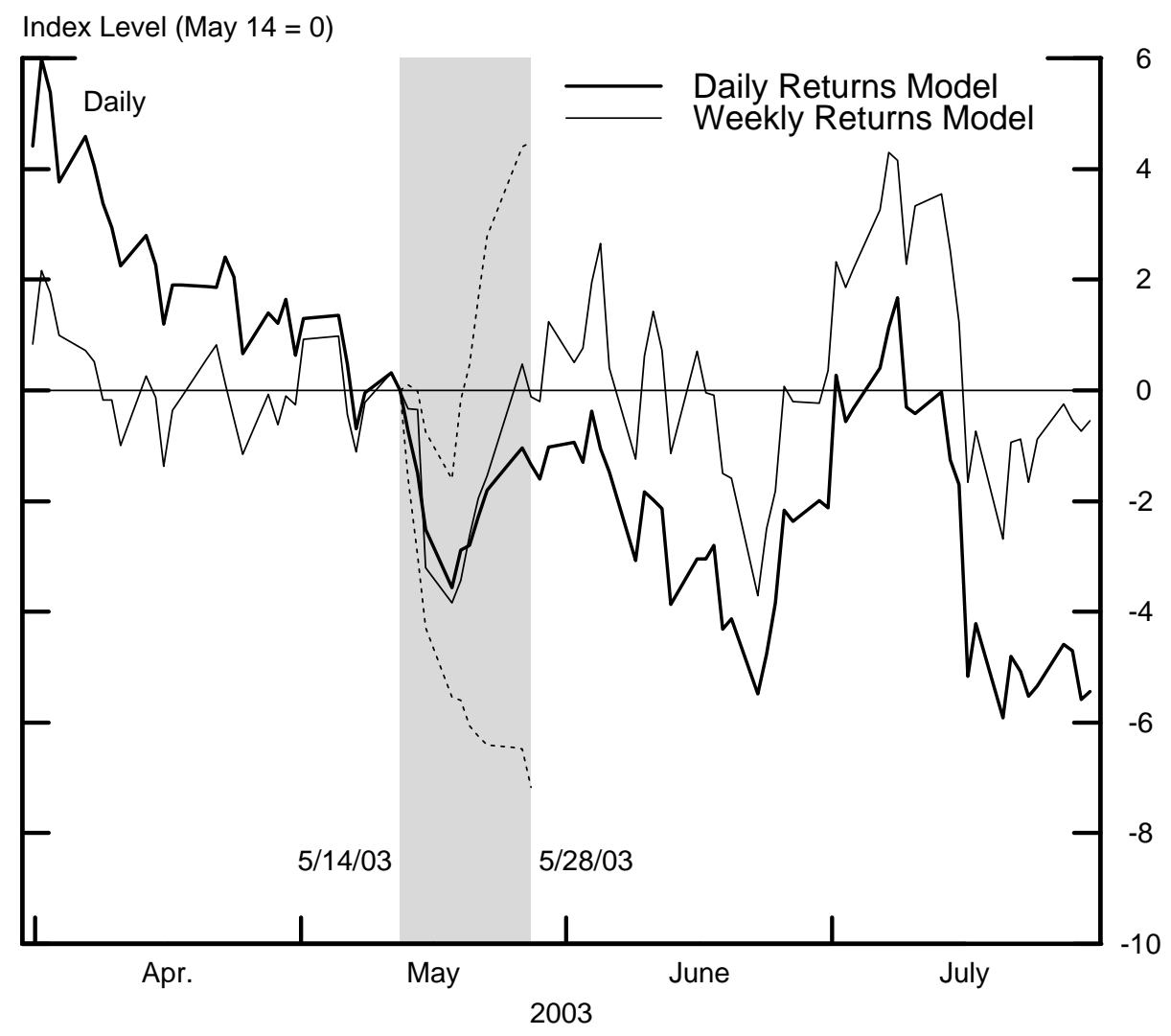


Figure 4

\section{S\&P 500 versus Bloomberg REIT Total Return Index}

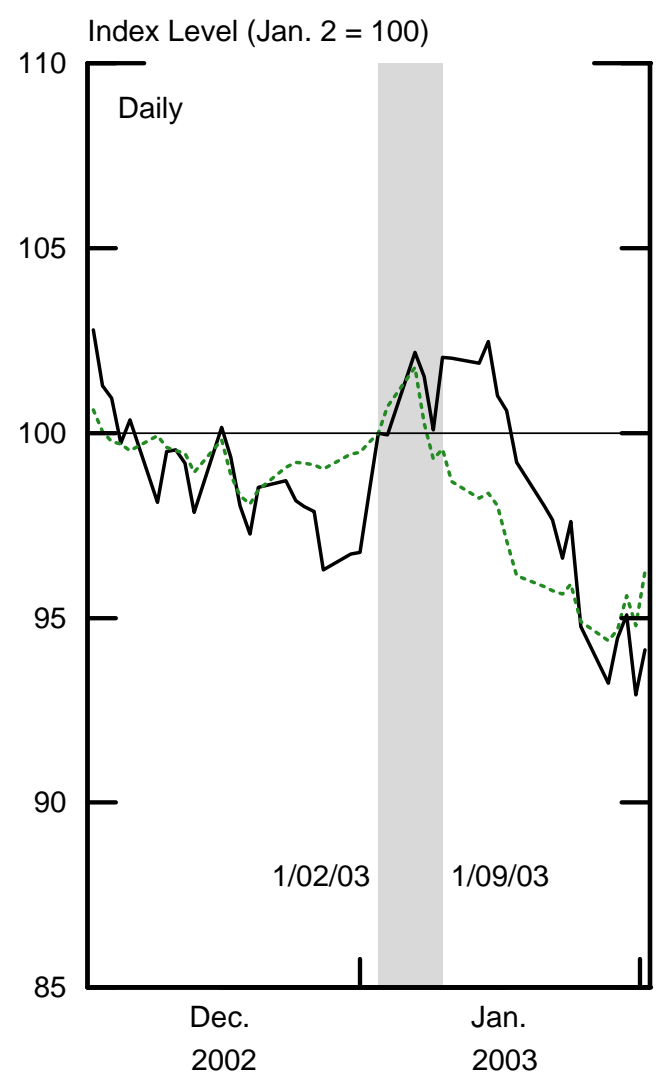

Realized Returns
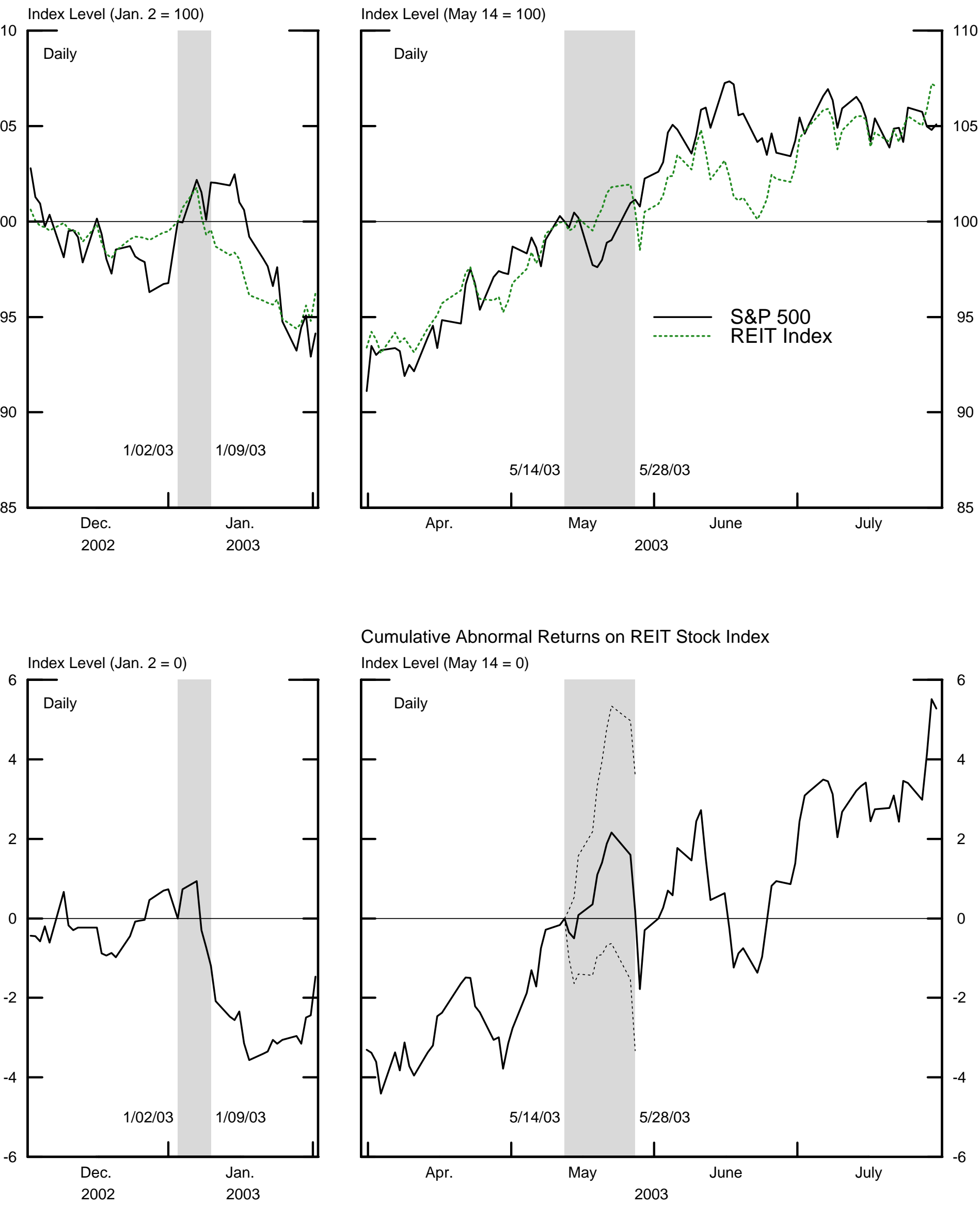

Cumulative Abnormal Returns on REIT Stock Index
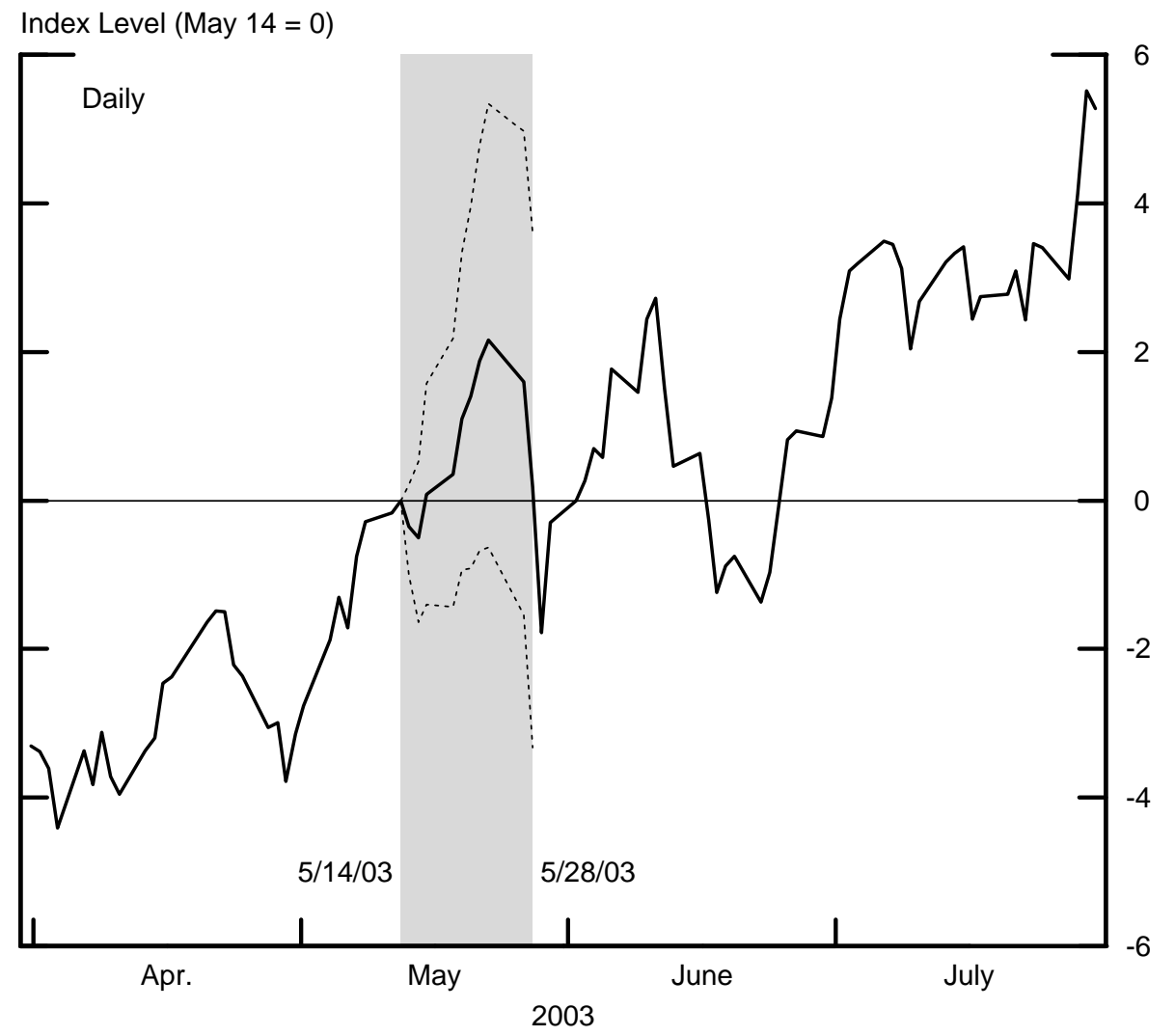
Figure 5

\section{Stock Returns by Dividend Intensity}

\section{Cumulative Realized Returns}

Index Level (Jan. $2=100)$

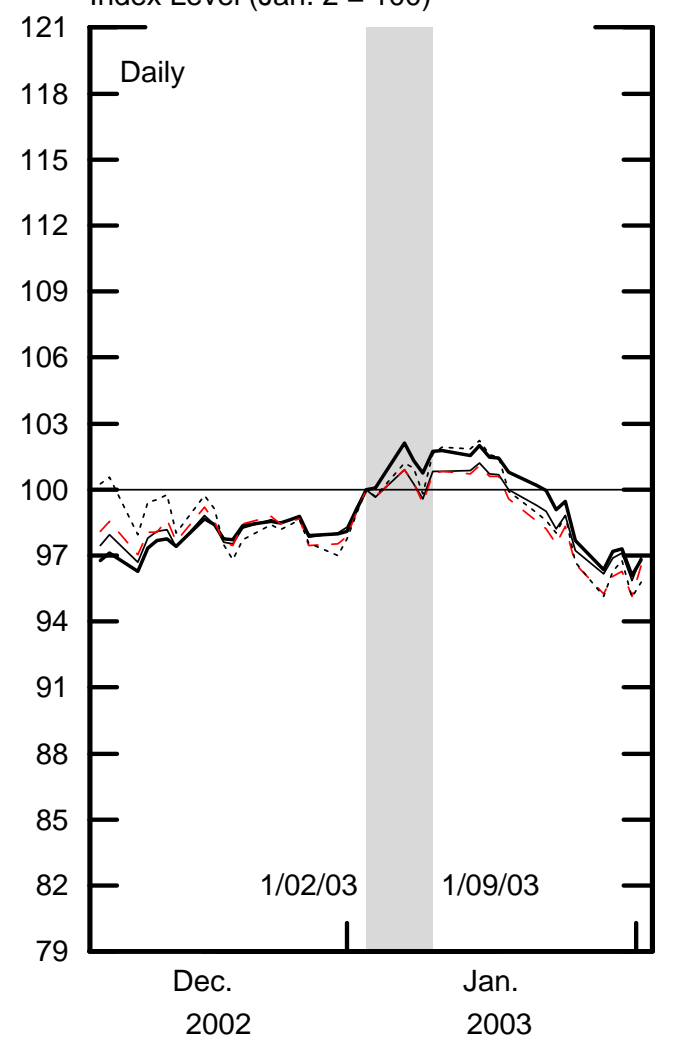

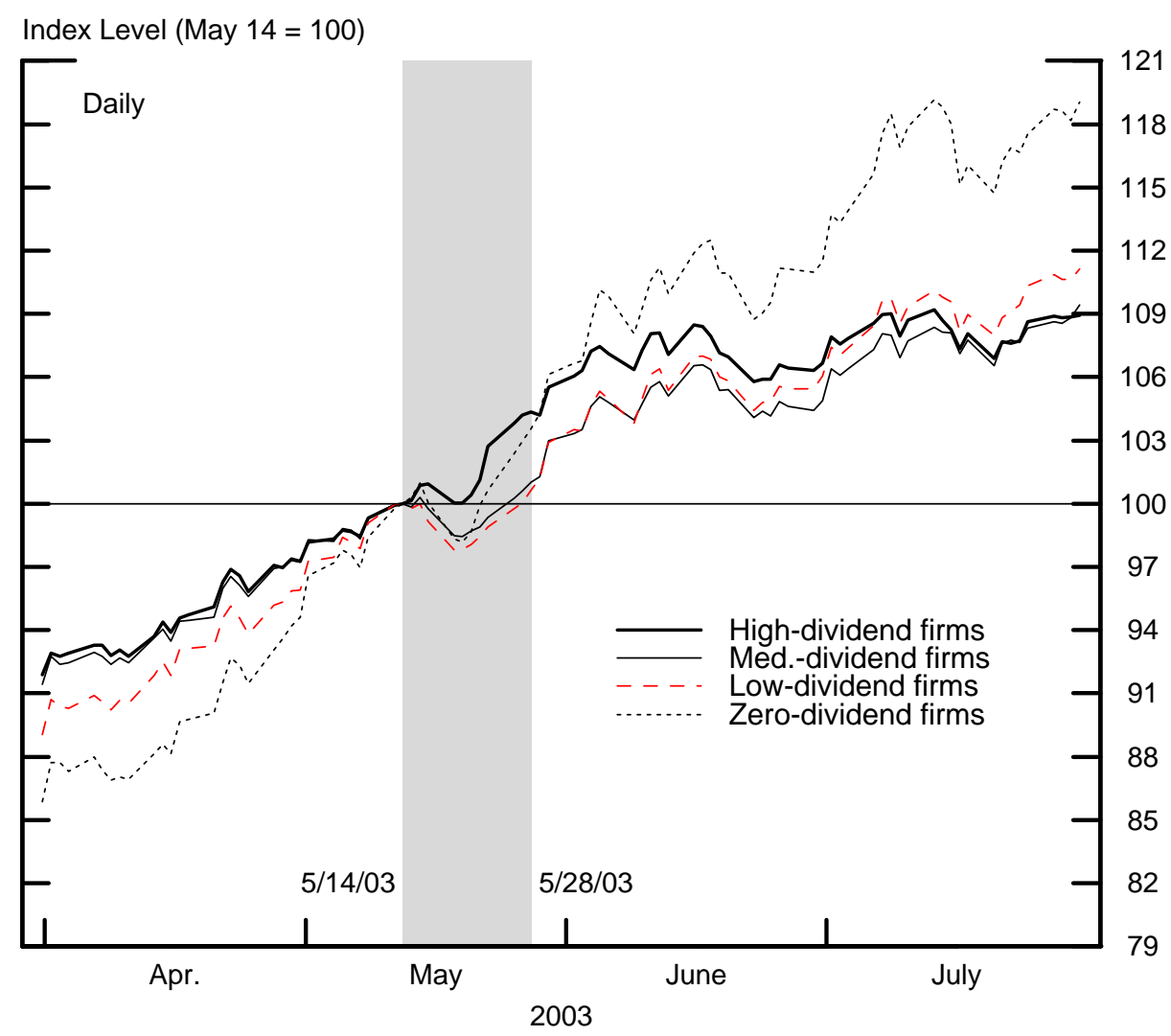

Cumulative Abnormal Returns

Index Level $($ Jan. $2=100)$

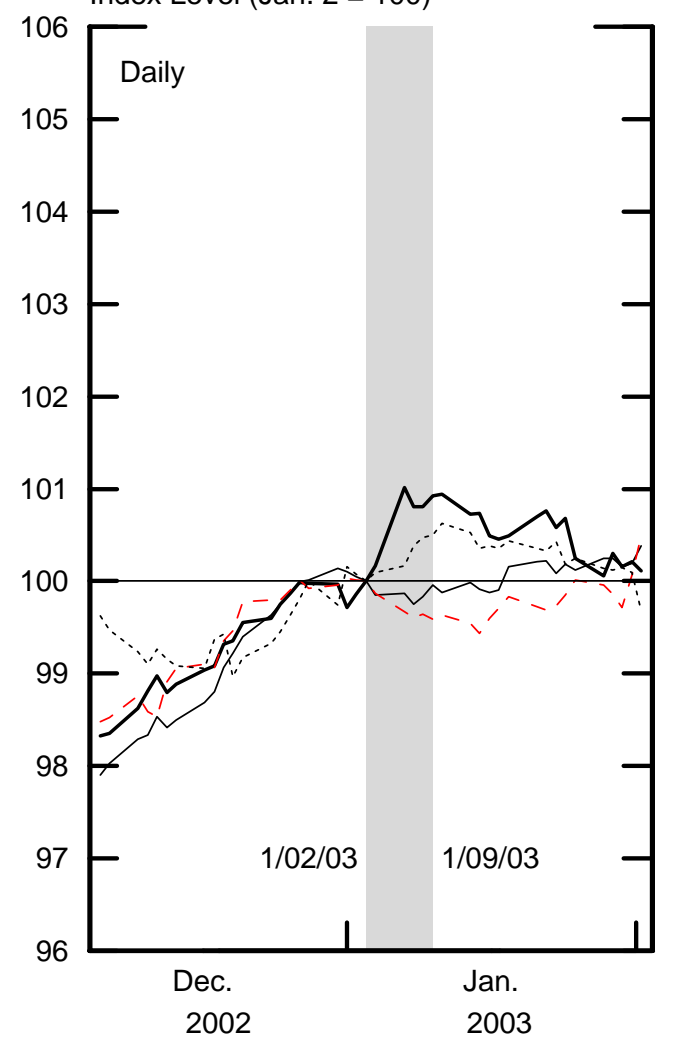

Index Level (May $14=100)$

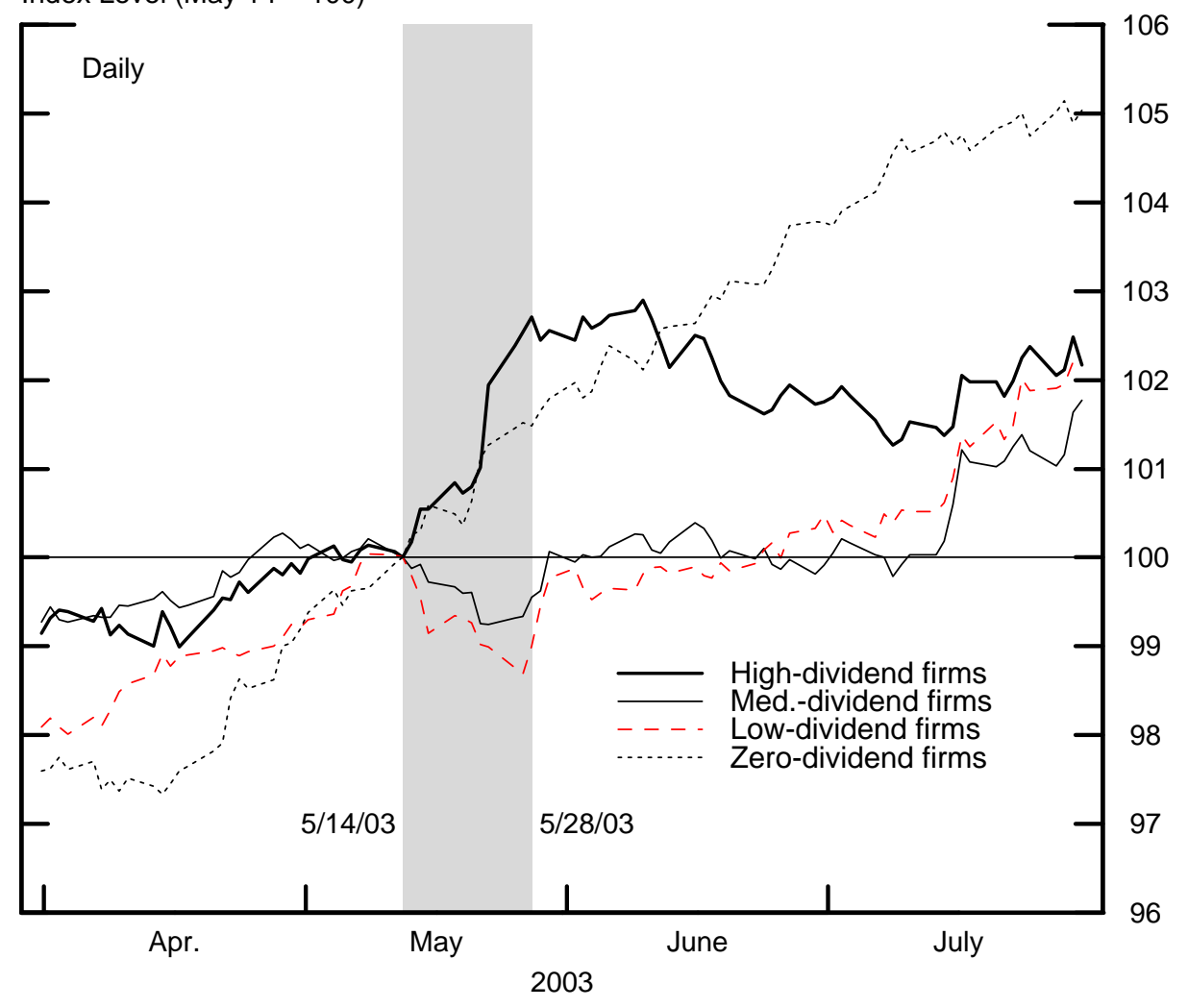


Figure 6

\section{Zero-Dividend Breakout}

Index Level (Jan. $2=100)$

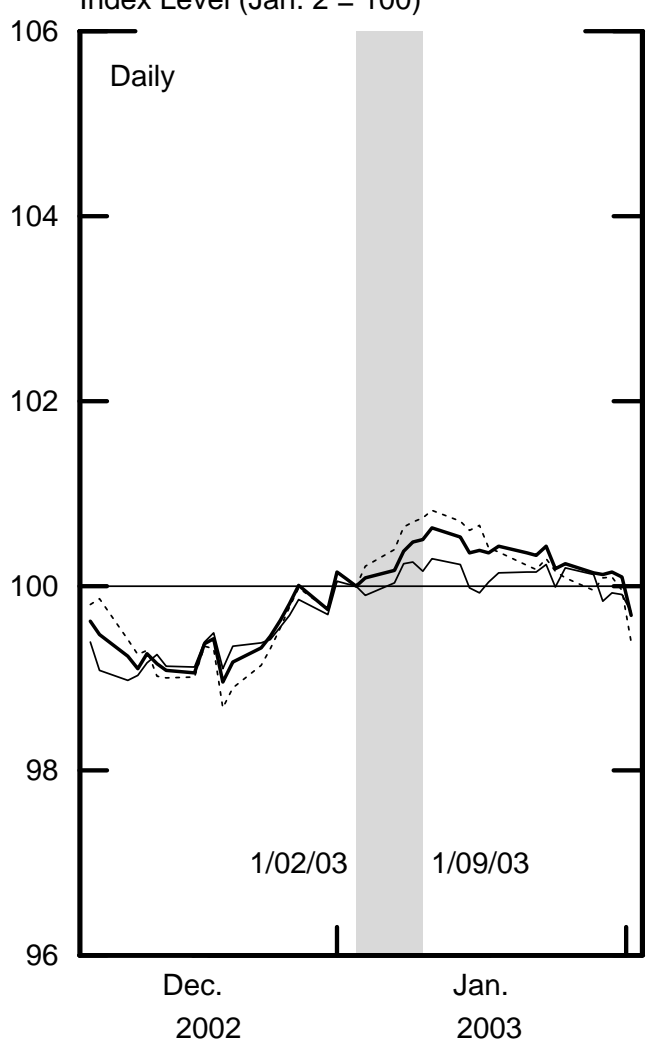

Cumulative Abnormal Stock Returns

Index Level (May $14=100$ )

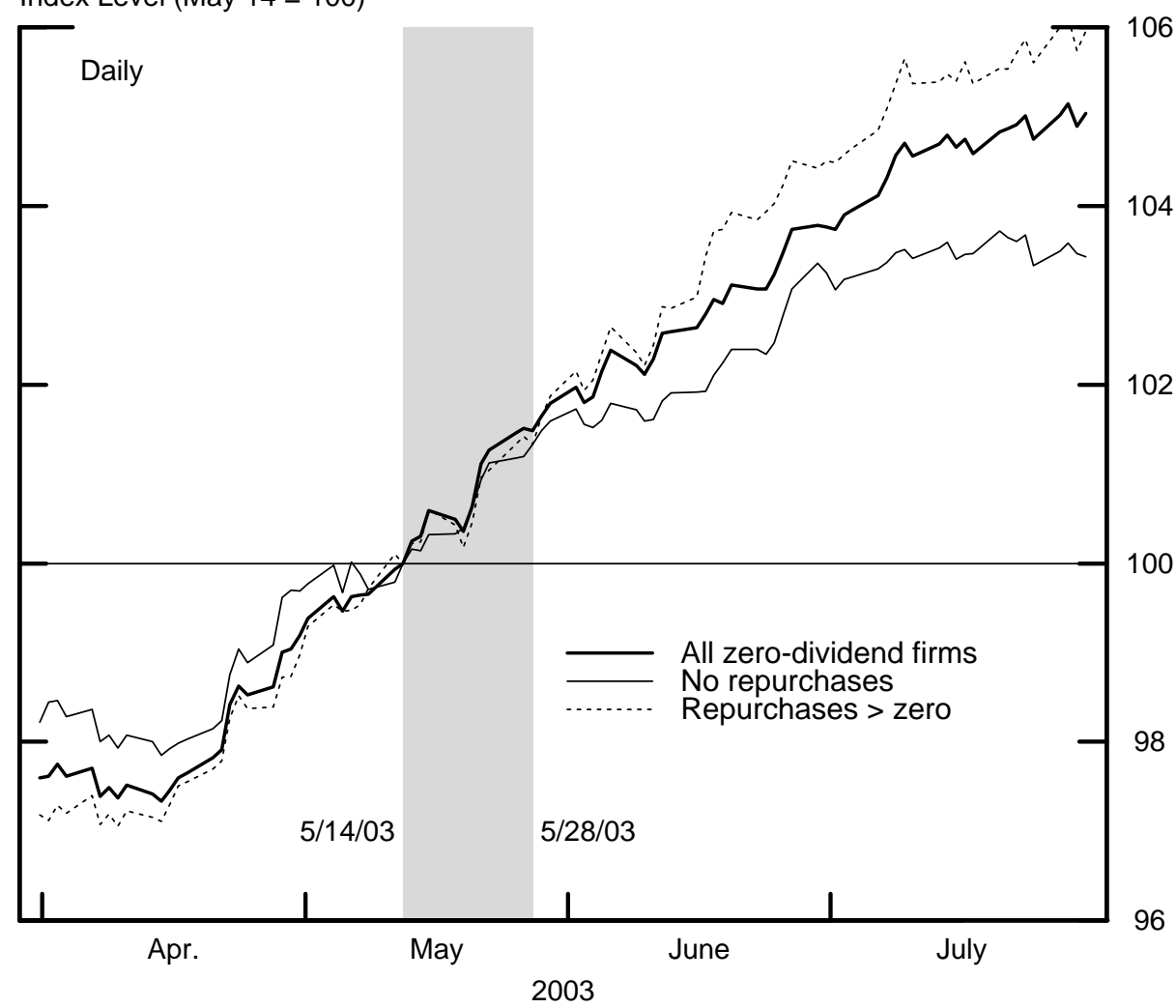


Figure 7

\section{Dividend Initiations and Growth}

Percent

20

15

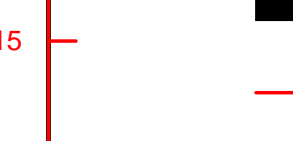

10

5

0

$-5$

0

(

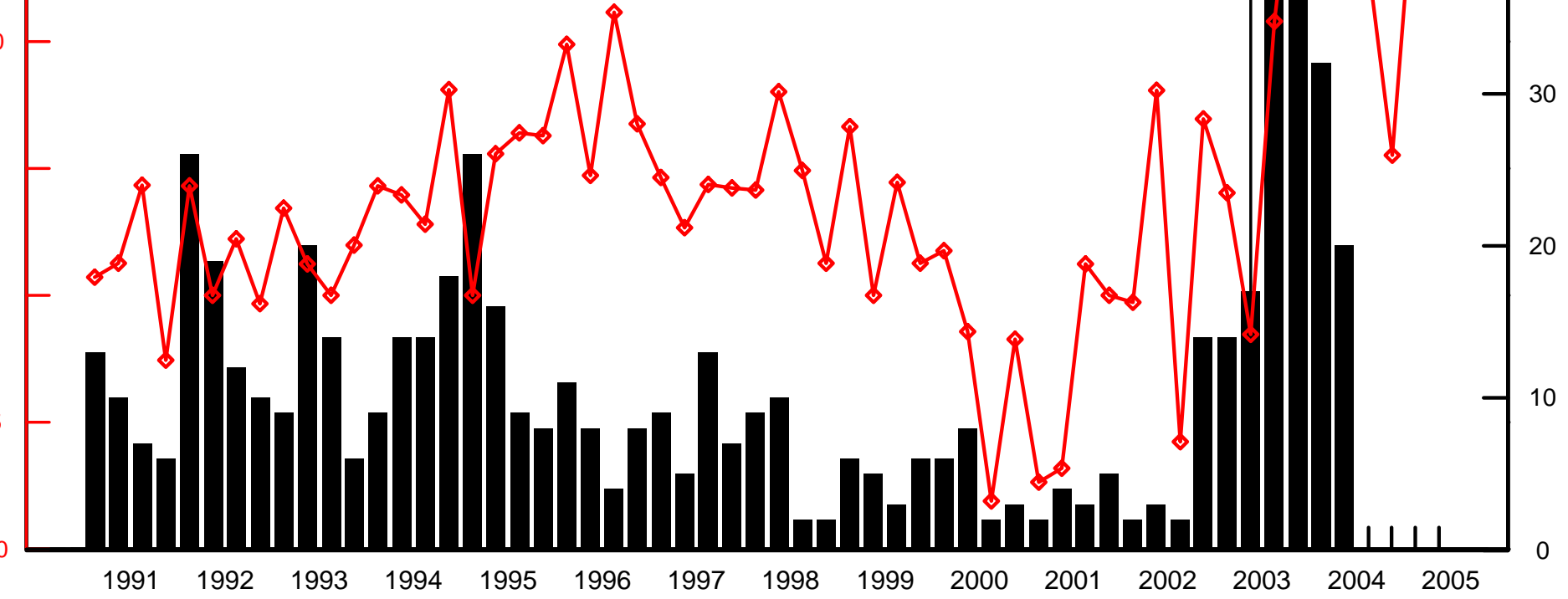

Source: Chetty, Raj and Emmanual Saez,"Dividend Taxes and Corporate Behavior: Evidence from the 2003 Dividend Tax Cut." Sep. 2004.

Number of Firms

S\&P 500 Dividends per share, 4-qtr growth (left scale) 
Table 1 - Description of Portfolios

\begin{tabular}{|c|c|c|c|c|c|c|c|c|}
\hline Portfolio & $\begin{array}{l}\text { Number } \\
\text { of Firms } \\
\end{array}$ & $\begin{array}{l}\text { Median } \\
\text { Assets } \\
(\$ \\
\text { millions) } \\
\end{array}$ & $\begin{array}{l}\text { Median } \\
\text { Dividend } \\
\text { Yield } \\
\text { (percent) } \\
\end{array}$ & $\begin{array}{l}\text { Median } \\
\text { Capx / Net } \\
\text { PPE } \\
\text { (percent) } \\
\end{array}$ & $\begin{array}{l}\text { Median } \\
\text { Cash* I } \\
\text { Assets } \\
\text { (percent) }\end{array}$ & $\begin{array}{l}\text { Median } \\
\text { LT Debt / } \\
\text { Assets } \\
\text { (percent) } \\
\end{array}$ & $\begin{array}{l}\text { Median } \\
\text { Csh Flow / } \\
\text { Capx } \\
\text { (percent) } \\
\end{array}$ & $\begin{array}{l}\text { 25th perc. } \\
\text { Csh Flow I } \\
\text { Capx } \\
\text { (percent) }\end{array}$ \\
\hline High-Dividend & 256 & 1351 & 4.1 & 11.8 & 3.5 & 22.8 & 161.0 & 104.2 \\
\hline Med-Dividend & 627 & 1559 & 1.8 & 13.7 & 4.8 & 14.4 & 212.2 & 145.1 \\
\hline Low-Dividend & 444 & 1525 & 0.6 & 16.2 & 5.9 & 14.2 & 209.0 & 117.2 \\
\hline Zero-Dividend & 1515 & 369 & 0.0 & 23.5 & 13.8 & 8.0 & 161.0 & 63.1 \\
\hline
\end{tabular}

* Cash includes short-term investments.

All firm statistics from year-end 2002 except Cash Flow / Capx, which is the median ratio of 1999, 2000, and 2002. 
Table 2A - Tests of Significance - January

\begin{tabular}{|c|c|c|c|c|}
\hline Portfolio & $\begin{array}{l}\text { C.A.R. } \\
\text { Jan } 2 \text { - } 9 \\
\text { (percent) } \\
\end{array}$ & $\begin{array}{l}\text { S.E. Residuals } \\
\text { from } \\
\text { Regression }\end{array}$ & $\begin{array}{l}\text { P - diff than } \\
\text { zero } \\
\end{array}$ & $\begin{array}{l}\mathrm{P} \text { - diff than } \\
\text { low div. }\end{array}$ \\
\hline High-Dividend & 1.23 & 0.0024 & 0.0192 & 0.0183 \\
\hline Med-Dividend & -0.15 & 0.0021 & 0.3880 & 0.3418 \\
\hline Low-Dividend & -0.45 & 0.0022 & 0.2026 & \\
\hline Zero-Dividend & 0.30 & 0.0029 & 0.3375 & 0.2007 \\
\hline \multicolumn{5}{|c|}{ Table 2B - Tests of Significance - May } \\
\hline Portfolio & $\begin{array}{l}\text { C.A.R. } \\
\text { May } 13 \text { - } 28 \\
\text { (percent) } \\
\end{array}$ & $\begin{array}{l}\text { S.E. Residuals } \\
\text { from } \\
\text { Regression }\end{array}$ & $\begin{array}{l}\text { P - diff than } \\
\text { zero }\end{array}$ & $\begin{array}{l}\mathrm{P} \text { - diff than } \\
\text { low div. }\end{array}$ \\
\hline High-Dividend & 2.70 & 0.0024 & 0.0004 & 0.0002 \\
\hline Med-Dividend & -0.52 & 0.0021 & 0.2268 & 0.2883 \\
\hline Low-Dividend & -1.09 & 0.0022 & 0.0691 & \\
\hline Zero-Dividend & 1.51 & 0.0029 & 0.0578 & 0.0158 \\
\hline
\end{tabular}


Table 3 - Summary Statistics of Payout Policy and Executive Stock-based Holdings

The table provides summary statistics of payout policy in 2003 and executive stock and option holdings in 2002 for 1,741 firms (roughly the S\&P 1500) in Execucomp in 2003. A dividend increase is defined as an increase in dividends per share (adjusted for stock splits). An increase in the dividend increase represents that a firm's change in dividends per share in 2003 exceeded the change in 2002. All variables are measured in percent.

Mean Median 25th -75 th $\%$

Payout Policy (Changes in 2003)

Probability Increase Dividends

$30.8 \quad 0.0 \quad 0.0-100$

Probability Initiate Dividends

Probability Dividend-Payer Increases Dividends

$\begin{array}{lll}6.8 & 0.0 & 0.0-0.0\end{array}$

$57.2 \quad 100.0 \quad 0.0-100$

Probability Dividend-Payer Increases the Increase in Dividends
44.3
$0.0 \quad 0.0-100$

Stock and Option Holdings (end of 2002)

Percent of Shares Held by Top Five Executives

$\begin{array}{lll}3.8 & 0.8 & 0.3-3.2\end{array}$

Value of Stock Held by Top Executives (\$M)

142.1

$11.7 \quad 3.3-40.0$

Options Held by Top Five Executives as percent of Shares Outstanding

$$
2.6
$$

$1.3-4.4$

Ratio of Number of Shares held by top five

executives to Number of Share and Options held

34.8

$25.5 \quad 11.4-53.6$

Dividends Received by Top Five Executives

(\$ thousands)

At firms that initiated dividends

4098.0

281.0

$51-902$

At dividend-payers that increased dividends

363.0

38.0

$12-194$ 
Table 4 - Likelihood of Dividend Initiation and Increase for Dividend-Payers, 2003

\begin{tabular}{|c|c|c|c|c|c|c|}
\hline \multicolumn{7}{|c|}{$\begin{array}{l}\text { The table presents linear regressions of whether a firm increases di } \\
\text { firms that did not pay dividends in } 2002 \text { (and thus for whom a divide } \\
\text { dividends in } 2002 \text {. A dividend increase is defined as a rise in divide } \\
\text { on the executive holding variables are reported. Other variables inc } \\
\text { book ratio, free cash flow-to-assets, cash on hand-to-assets, debt-to } \\
\text { log of market value, and firm age and industry indicator variables. T } \\
\text { heteroskedasticity (i.e., robust standard errors). }\end{array}$} \\
\hline & \multicolumn{2}{|c|}{ All Firms } & \multicolumn{2}{|c|}{ Dividend Initiation } & \multicolumn{2}{|c|}{$\begin{array}{l}\text { Dividend Increase for } \\
\text { Dividend Payers }\end{array}$} \\
\hline & (1) & (2) & (3) & (4) & $(5)$ & (6) \\
\hline $\begin{array}{l}\text { Fraction of Shares Held by Top } \\
\text { Five Executives }\end{array}$ & $\begin{array}{l}48.9^{\star \star} \\
(17.6)\end{array}$ & & $\begin{array}{l}35.8^{\star} \\
(17.9)\end{array}$ & & $\begin{array}{l}85.2^{\star \star} \\
(33.2)\end{array}$ & \\
\hline $\begin{array}{l}\text { Options Held by Top Five } \\
\text { Executives Normalized by Shares } \\
\text { Outstanding }\end{array}$ & $\begin{array}{l}-122.0^{*} \\
(53.8)\end{array}$ & & $\begin{array}{c}-99.5^{\star} \\
(42.7)\end{array}$ & & $\begin{array}{c}-51.4 \\
(138.2)\end{array}$ & \\
\hline $\begin{array}{l}\text { Ratio of \# of Shares held by Top } \\
\text { Five Executives Normalized by \# } \\
\text { of Shares \& Options Held by Top } \\
\text { Five Executives }\end{array}$ & & $\begin{array}{c}19.6^{\star \star} \\
(4.5)\end{array}$ & & $\begin{array}{c}12.9^{\star \star} \\
(4.4)\end{array}$ & & $\begin{array}{c}21.0^{\star \star} \\
(8.3)\end{array}$ \\
\hline Other variables? & Yes & Yes & Yes & Yes & Yes & Yes \\
\hline Adjusted $\mathrm{R}^{2}$ & 0.388 & 0.39 & 0.403 & 0.399 & 0.445 & 0.444 \\
\hline Number of Observations & 1,352 & 1,352 & 685 & 685 & 667 & 667 \\
\hline
\end{tabular}

${ }^{* *}$ and ${ }^{*}$ denote significance at the 1 percent and 5 percent levels, respectively. 
Table 5 - Payout Substitution? Change in Share Repurchases and Total Payouts for Dividend-Increasing Firms

\begin{tabular}{|c|c|c|c|c|c|c|}
\hline \multirow[b]{3}{*}{ Sample } & \multicolumn{6}{|c|}{ Repurchases and Total Payouts } \\
\hline & \multicolumn{2}{|c|}{$\begin{array}{l}\text { Percent of firms that } \\
\text { repurchased shares }\end{array}$} & \multicolumn{2}{|c|}{$\begin{array}{l}\text { Percent of firms that } \\
\text { reduced repurchases } \\
\text { (given repurchased in } \\
\text { previous year) }\end{array}$} & \multicolumn{2}{|c|}{$\begin{array}{c}\text { Percent of firms that } \\
\text { increased total payouts }\end{array}$} \\
\hline & $1993-2002$ & 2003 & 1993-2002 & 2003 & 1993-2002 & 2003 \\
\hline $\begin{array}{l}\text { Firm Initiates } \\
\text { Dividends }\end{array}$ & 38 & $68^{\star \star}$ & 56 & $78^{\star *}$ & 89 & $66^{\star \star}$ \\
\hline $\begin{array}{l}\text { Firm Increases } \\
\text { Dividends } \\
\text { (Dividend Payer) }\end{array}$ & 66 & 66 & 55 & $62^{\star \star}$ & 55 & $49^{\star \star}$ \\
\hline
\end{tabular}

**indicates statistic in 2003 is different from statistic for 1993 to 2002 at the $5 \%$ level. 
Appendix - Equity Issuance Probabilities*

\begin{tabular}{|c|c|c|c|c|}
\hline \multirow[b]{2}{*}{ Percent Issuing Equity from: } & \multicolumn{3}{|c|}{ Firms with No Dividends } & \multirow[t]{2}{*}{ Firms with Dividends } \\
\hline & Repurchases & $\begin{array}{c}\text { No } \\
\text { Repurchases } \\
\end{array}$ & All & \\
\hline Jan 1999 to Apr 2003 & $30.2 \%$ & $40.1 \%$ & $37.1 \%$ & $18.1 \%$ \\
\hline June 2003 to Aug 2005 & $4.7 \%$ & $8.7 \%$ & $7.0 \%$ & $6.7 \%$ \\
\hline
\end{tabular}

*Equity issuance data from SDC 